\title{
AN EMPIRICAL ANALYSIS FOR THE PERCEPTIONS OF AMMAN STOCK EXCHANGE'S INVESTORS
}

\author{
Mohammad Sami ALI (1D* \\ Zarqa University, The Faculty of Economics and Administrative Sciences, \\ Banking and Finance Department, Zarqa Governorate, Jordan
}

Received 16 September 2019; accepted 10 January 2020

\begin{abstract}
Research problem: Although the economy of Jordan witnessed dramatic volatilities and fundamental variables including market-to-book value ratio and interest rate are located at the middle of these variations; there is a lack in literature regarding the impacts of market fundamentals and dividends policies in investors' perceptions, as captured by the performance of Amman stock exchange.

Research objectives: Thus, due to the power of these variables to impact investment decisions, this research aimed at scrutinizing the long and short-run causalities, which are running from market fundamentals, dividends policies, and the 2008/11 financial crisis towards investor' perceptions.

Research methodology: To accomplish the core aim of this research, empirical techniques like Augmented Dickey Fuller, Johansen Co-integration, the single equation of the error correction model "ECM" and the Wald test are mainly utilized to analyze a time series data set covering the period Jan/1990-Dec/2017.

Results and future recommendations: Consequently, results from ECM confirmed that the study's variables are not integrated over the long-run. Alternatively, findings from the Wald test approved that investors' perceptions as captured by the market's performance are statistically related to market fundamentals, dividends policies and the recent financial crisis. Therefore, the study concluded that ASE's investors adopt the view of Gordon (1962) and Lintner (1962) during the short-run. However, the study recommends further researchers to follow the study's models to investigate the other variables, which are impacting investors' perceptions, as well as examining the impact of financial crises in the decisions of dividends' policies.
\end{abstract}

Keywords: market fundamentals, dividends policies, buffet indicator, M/BV, interest rates, investors' perception, ECM.

JEL Classification: E44, G12, D53, G01, G21, G40.

\section{Introduction}

Since stock markets' performance normally respond to investors' attitudes; evaluating the impact of dividends policies in their behaviours became a core interest of researchers in the field of corporate finance. For instance, authors including Gordon (1962) argued that dividends' policies are significantly influencing a share's market price, since they are commonly used by investors to evaluate a firm's performance. Likewise, in a previous research Gordon (1959) confirmed that investors prefer to acquire the share, through focusing on its income, instead of capital gains. Consistently, studies including Lintner (1962) affirmed that a firm's value is significantly related to the firm's dividends policies, since the decision of distributing dividends stimulates investors to acquire a firm's share. Continuously, Aharony and Swary (1980) confirmed that when companies' managers decide to distribute profits that will be seen by investors as good news, which in turn increasing a stock price, due to the increase of a stock's demand, and vice versa. Paradoxically, authors including Miller and Modigliani (1961) debated that dividends policies do not affect a firm's value; rather it is impacted by the firm's investment policies. To some extent this view agrees with Black and Scholes (1974) as they detected a non-significant correlation between stock prices along with the change in a firm's dividends policies.

Furthermore, since the economy of Jordan witnessed structured variations and variables like $\mathrm{M} / \mathrm{BV}$ ratio and interest rates lie at the heart of these movements; it is imperative to assess the efficiency of these variables to impact investors' perceptions. More specifically, during the period 2011-2017, metrics such as M/BV plunged from 1.4 to 1.2 , and similarly for saving deposits' interest rates

${ }^{\star}$ Corresponding author. E-mail: mode_alwredat@yahoo.com 
as they decreased by $1 \%$, while the rate of interest on time deposits increased from $3.5 \%$ to 3.8 , during the same period. Thus, due to the importance of these variables to the process of decision making, there are numerous studies conducted to find out their impacts in investment decisions. In this regard, researchers including Ali (2016b), Thang (2009), Aurangzeb (2012), El-Seoud (2014) confirmed that variables such as interest rates and M/BV ratio conduct a vital role in shaping investors' decisions. By contrast, a study by Ali (2018b) argued that there are no short or long-run causalities running from interest rates towards investors' behaviour as captured by the stock market liquidity.

Anyway, though many studies including Ali (2016a, 2016b, 2018a, 2018b), Thang (2009), El-Seoud (2014) examined the potential determinants of investors' behaviour; there is gap in literature regarding the impacts of market fundamentals and dividends policies in the perceptions of ASE's investors as captured by market's performance. Furthermore, that since the current literature confirmed that the economy of Jordan such as other emerging economies was affected by this crisis (Neaime, 2012; Al-Najjar et al., 2010) the study also seeks to understand the role of this financial turmoil to affect investors' perceptions, over the period Jan/1990-Dec/2017. Thereby, results from this research are expected not only to assist investors to understand the role of dividends policies and market fundamentals in the process of decision making, but it will also assist them to make rational investment decisions during both the tranquil and the unstable financial periods. Beyond that, the study attempts to determine whether or not ASE's investors include the views of Gordon (1959) and Lintner (1962), when they decide to invest in the stock market. For this purpose, the study applied the ADF to check the stationarity of the used time series data, and thus since the unit root was only eliminated after including the first difference, the study ran the Johansen test to check for long-run integrations. Subsequently, the study employed the single equation of the error correction model in order to accept or reject results from Johansen test. However, since the study seeks to check the short-run causalities which are running from dividends policies, market fundamentals and financial crisis towards investors' perceptions, the Waldgranger test was also utilized.

\section{Empirical review and research question}

This research investigated the effectiveness of market fundamentals and dividends policies to explain investors' perceptions as captured by the performance of ASE, over the period Jan/1990-Dec/2017. Thus, to highlight the gap in literature; this section presents some of the most related studies, which are concerned with investors' behaviour and stock markets' performance. Thereafter, the section proceeds to provide a critical appraisal for the impacts of the recent financial crisis in the economy of Jordan in general, while on the Amman stock exchange in more details.

\section{Stock market performance's related studies}

The review of literature revealed that there was a great attention given to scrutinize the variables, which are impacting stock markets' performance. For instance, in an attempt to identify the determinants of stock market performance (Zafar, 2013) showed a negative correlation between interest rates and the market's performance as gauged by market capitalization/GDP. However, Khrawish, Siam, and Jaradat (2010), Ologunde, Elumilade, and Saolu (2006) affirmed that the market capitalization is positively relating to interest rates. However, researchers including Thang (2009) confirmed a negative correlation between the stock index of Malaysian stock market and interest rates during the short as well as long-run. Therefore, the study induced that the increase in interest rates motivates investors to liquidate their securities to deposit them into the banks, and vice versa. Consistently, Richard, Adekunie, and Ojodu (2012) showed that the Nigerian stock market's index is adversely responding to the movements of interest rates. According to Al-Mukit (2012) the weighted average saving deposits rates are negatively associated with the market's index. Likewise, Aurangzeb (2012) confirmed a negative correlation between interest rates and the stock market's performance. Where, a $1 \%$ increase in deposit interest rates decreases the market's performance roughly by $73 \%$, while the decrease in these rates motivates investors to withdraw their money to invest them in stocks. Anyway, a study by Seetharaman and Raj (2011) confirmed that the stock prices of Malaysian listed banks are positively linked with the earnings per share ratio. By contrast, Balaputhiran (2014) debated that the stock prices of Sri Lanka listed banks are insignificantly related to earnings per share ratio. Consistently, Balakrishnan (2016) affirmed that the share prices of the Pharmaceutical sector, which is listed in New York stock exchange, are not influenced by the movements of earnings per share. However, in an attempt to examine the effect of oil price on stock returns in Shangahi stock exchange (Khan et al., 2019) utilized the Autoregressive distributed lag to analyze a monthly data set covering the period Jan/2000-Dec/2018. Consequently, the results showed that stock returns are negatively related to the monthly increase in oil prices during the short as well as long-run. Nevertheless, the decrease in oil prices is found to be positively adjusting stock returns.

\section{Factors affecting investors' behaviour}

Due to the significance of behavioural finance, there are numerous researches performed to identify the influential factors of investors' behaviour. In this regard, (Ali, 2018b) confirmed that there are long and short-run causalities running from interest rates and $\mathrm{M} / \mathrm{BV}$ ratio towards ASE's liquidity as captured by the number of transactions. A study by Shaban and Al-Zubi (2014) confirmed that variables like $\mathrm{M} / \mathrm{BV}$ ratio and $\mathrm{P} / \mathrm{E}$ ratio are significantly influencing the decisions of Jordanian investors. As it was included by Yamin and Ali (2014) M/BV 
ratio is significantly impacting the decisions of Amman stock exchange's investors. Mojgan and Ali (2011) revealed that variables like EPS and DPS conduct a central role in stimulating Persian investors to invest in stock markets. Anyway, Azam and Kumar (2011) pointed out that variables like E/P ratio, FDI and the real GDP are significantly influencing the stock index of Karachi stock market's as a proxy for investors' behaviour. According to Harsha and Kerav (2012) the decisions of Indian investors who are residing in Vadodara and Ahmedabad, are highly influenced by the market capitalization rate and companies' past performance, while variables such as market's indices are found to be weakly affecting investors' decisions.

\section{The recent financial crisis's implications}

Such as other emerging economies in the MENA region countries; the economy of Jordan was not forgiven from the impacts of the 2008/11 financial turmoil. Therefore, the study revised some of the previous researches, which are slighted the light on the impacts of this crisis in investors' behaviour and the country's economy as a whole. In this context, studies including Ali (2018a, 2016b) confirmed that the behaviour of Jordanian investors as measured by the stock market's performance was adversely influenced by this global crisis. In the same vein, Al-Najjar et al. (2010) found that though the economy of Jordan was adversely impacted by this catastrophe; the lack of innovative financial instruments in ASE succeeded in mitigating the crisis's impacts. Further results showed that the listed financial sectors recorded a considerable decline, due to the weak performance of the banking sector's index. Continually, Al-Zyadat and Al-Kharabsheh (2013) revealed that the global crisis impacted the performance of ASE as monitored by stock prices and the turnover ratio. Additionally, the higher interest rates resulted in decreasing stock prices and the lending activity of Jordanian commercial banks. Likewise, Neaime (2012) found that since a majority of MENA region countries are highly relied on the FDI and exports to recover budget deficit; the study showed that countries including Jordan were negatively impacted by this crisis, due to the dramatic decline in FDI. Moreover, since there is a gap in literature regarding the influential variables of investors' perceptions as captured by the Buffet indicator, the general stock index and the number of transactions, the current research aimed at answering the impact of market fundamentals, dividends policies as well as financial crisis in the performance of ASE as a main proxy for investors' perceptions. According to this research the term market fundamentals relates to the weighted average time deposit interest rates "WATDIR, weighted average saving deposit interest rates "WAS$\mathrm{DIR}$, and the average ratio of ASE's M/BV ratio. On the other hand, the dividends' policies indicator are including the price to earnings ratio " $\mathrm{P} / \mathrm{E}$ " the dividends yield ratio "DYR" and the earnings per share ratio "EPS".

\subsection{Research methodology, hypotheses and data sources}

This research attempts to accomplish the core aim and objectives through hypothesizing that the performance of ASE "ASEP" is significantly related to the volatility in the WATDIR, WASDIR, M/BV, EPS and DYR. Additionally, the study assumed that the RFC_2008/11 was significantly impacted the perceptions of ASE's investors. Thus, since this research is primarily aimed at testing hypotheses those are built from the available literature, the positivism paradigm was adopted to achieve the core objectives of this research. Which in other words, the study used the deductive approach that is linked with the quantitative method to test hypotheses and getting a valid knowledge (Ali, 2016b). Therefore, the study used a set of empirical measurements such as the ADF, Johansen Co-integration, ECM and the Granger Causality Wald tests in order to analyze a monthly time series data set covers the period Jan/ 1990-Dec/2017. The used data was mainly obtained from the statistical bulletins of Amman stock exchange, central bank of Jordan, and the official sites of the global economy and the World Bank (ASE, 2018; CBJ, 2018; Global Economy, 2018; World Bank, 2018). However, to explore the impacts of the 2008/11 recent financial crisis in investors' perceptions, the study constructed a dummy variable within two values. Where, the 1 indicates that this crisis was significantly impacted investors' perceptions, while the zero value assumed that investors' perceptions were not impacted by this crisis. However, one of the main reasons behind using the set of the aforementioned techniques is ensuring validity. In this regard, Saunders et al. (2012, p. 323) mentioned that researchers can get valid results through relying on measurements those are similar to what were used by previous related researches. Thus, since researchers including (Ali, 2016b, 2018a, 2018b; Azam \& Kumar, 2011; Thang, 2009) used similar measurements to test the market performance, the measures of this research are supposed to be valid. Therefore, to accomplish the core aim of this study the model specification and variables' measurements are addressed below.

\subsection{Model specification and variables measurements}

In order to attain the primary aim of this research, the following model was intended to be tested. However, since results from Augmented Dickey Fuller test revealed that the examined variables only became stationary after converting them into the first difference; this model was replaced by Model number 3 as shown in the coming estimation procedure:

$$
\begin{aligned}
& \operatorname{LnIP}=\beta_{0} \pm \beta_{1} \sigma W A T D I R \pm \beta_{2} \sigma W A S D I R \pm \\
& \beta_{3}\left(\sigma \frac{M}{B V} \%\right) \pm \beta_{4} \sigma E P S \pm \beta_{5} \sigma \frac{E}{P} \pm \beta_{6} \sigma D Y R \pm \\
& \beta_{7} A S E P \pm \beta_{8} \frac{R F C_{2008}}{11}+\varepsilon_{t}
\end{aligned}
$$


where, the IP on the left side refers to the logarithm of investors' perceptions as captured by the market's performance indicators. Similarly, the ASEP on the right side refers to the performance of ASE. For instance, if the buffet indicator is placed on the left side; the general stock index and the number of transactions will be used on the other side, to evaluate their impacts on investors' perceptions. $\sigma W A T D I R$ refers to the volatility in the weighted average time deposit interest rates and the $\sigma W A S D I R$ is the volatility in saving interest rates, $\left(\sigma \frac{M}{B V} \%\right)$ relates to the market-to-book value ratio, $\sigma E P S$ is the variations in the earnings per share, $\sigma \frac{E}{P}$ is the earnings to price ratio, and $\sigma \mathrm{DYR}$ relates to the movements in the dividend yield ratio. The RFC_2008/11, is a dummy variable constructed to capture the impacts of financial crisis in investors' perceptions. Moreover, the utilized variables are calculated as shown below:

$$
\text { Buffet Indicator }=\frac{\text { Stock Market Cap }}{\text { GDP }} \times 100 .
$$

- Indext $=\frac{\sum_{i=1}^{n} P_{t i} \times S_{t i} \times F_{t i}}{D_{t}}$ : where the $P_{t i}$ is the closing price of company $i$, on time $t$, the $S_{t i}$ is the number of listed shares of company $i$, on time $t$, the $F_{t i}$ is the factor of company $i$, on time $t$ and the $D_{t}$ relates to index's divisor on time $t$.

- No. of Transaction $=\sum T N C_{t}$ : where the TNC refers to the total number of executed bought or sold contracts in the time $t$ "one month".

The Average Ratio of ASE's $\frac{M}{B V}=\frac{A S E^{\prime} \text { s market value }}{A S E^{\prime} \text { s book value }}$.

- WATDIR $=\frac{\sum W A T D I R^{J B}}{13}:$ Relates to the summa-

tion of the weighted average time deposit interest rates of Jordanian commercial banks, divided by the total number of Jordanian commercial licensed banks.

- WASDIR $=\frac{\sum W A S D I R^{J B}}{13}$.

- EPS $=\frac{A N P L C_{t}}{A O S_{t}}:$ The NPLC relates to the average net profit of listed companies, divided by the average of outstanding shares during the time $t$.

$-\frac{P}{E}=\frac{A M P_{t}}{A E_{t}} \times 100:$ Relates to the average of market closing prices in a specified period of time relative to the average amount of shares earning during the same period "one month".

- DYR $=\frac{A C D P S_{t}}{A C S P_{t}} \times 100:$ The ACDPS relates to the average of companies' dividends per share, divided by the average of companies' stock prices during the time $t$.

- RFC_2008 / 11: Is a dummy variable used to capture the impacts of the recent financial crisis.

\section{Estimation procedure}

To avoid the problem of getting spurious regression results, the study employed the $A D F$ test to check for data stationarity. Therefore, the following model was examined:

$$
\Delta Y_{t}=\delta_{0}+\delta_{1}+\delta_{2} Y_{t-1}+\sum_{i=1}^{p} \alpha \Delta Y_{t-1}+\varepsilon_{t},
$$

where, $\delta_{0}, \delta_{1}, \delta_{2}$ and are the parameters to be estimated and the $\varepsilon$ t relates to the disturbance term. Since results from this model revealed that the tested variables only became stationary after adding the first difference, the study employed the Johansen co-integration test, and subsequently it is found that there is an existence of the adjustment mechanism. This mechanism was examined through running the single equation of the restricted vector error correction model "VECM". Thus, since model number (1) was replaced by model number (3), the following ECM follows the order of specification of the first model:

$\Delta L n I P_{i t}=\beta_{0} \pm \sum_{i=1}^{k-1} \beta_{1 i} \Delta I P_{t-1} \pm \sum_{i=1}^{k-1} \beta_{2 i} \Delta \sigma . W A T D I R_{t-1} \pm$

$\sum_{i=1}^{k-1} \beta_{3 i} \Delta \sigma . W A T D I R_{t-1} \pm \sum_{i=1}^{k-1} \beta_{4 i} \Delta\left(\sigma \cdot \frac{N}{B V} \%\right) \pm$

$\sum_{i=1}^{k-1} \beta_{5 i} \Delta \sigma$

of the first model.ce of adjustment mechanism.e, ly be

$\sum_{i=1}^{k-1} \beta_{6 i} \Delta \sigma \cdot \frac{E}{P_{t-1}} \pm \sum_{i=1}^{k-1} \beta_{7 i} \Delta \sigma D Y R_{t-i} \pm$

$\sum_{i=1}^{k-1} \beta_{8 i} \Delta A S E P_{t-1} \pm \sum_{i=1}^{k-1} \beta_{9 i} \Delta W A T D I R_{t-1} \pm$

$\sum_{i=1}^{k-1} \gamma_{2} \sigma . W A S D I R_{t-1} \pm \sum_{i=1}^{k-1} \gamma_{3}\left(\sigma \cdot \frac{M}{B V} \%\right) \pm$

$\sum_{i=1}^{k-1} \gamma_{4} \sigma . E P S_{t-1} \pm \sum_{i=1}^{k-1} \gamma_{5} \sigma \frac{E}{P_{t-1}} \pm \sum_{i=1}^{k-1} \gamma_{6} \sigma . D Y R_{t-i} \pm$

$\sum_{i=1}^{k-1} \gamma_{7} A S E P_{t-1} \pm \sum_{i=1}^{k-1} \gamma_{8} R F C_{-} 2008 / 11_{t-1} \pm \psi_{i} \varepsilon_{t-1} \pm \mu_{t}$,

where, $\Delta L n I P_{i t}$ is the first difference operator of the dependent variable that relates to investors' perceptions. $\beta_{i}$ : $i=1 \ldots .9$ are the parameters to be estimated and they are indicating to the coefficients of the short-run dynamics. While the $\gamma i: i=1 \ldots 8$ refers to the long-run multipliers. $\psi_{i}, \varepsilon_{t-1}$ is the first lagged period of the error correction term and $\mu_{t}$ refers to the white noise error term with the usual properties. Thus, to test whether the independent variables cause granger to investors' perceptions during the long-run; the above model assumes that the error 
Table 1. ADF test's results

\begin{tabular}{|c|c|c|c|c|c|c|}
\hline Variable & \multicolumn{2}{|c|}{ Level 5\% } & P-Value & $1^{\text {st }}$ Diff & Remark & $\mathrm{H}_{0}$ \\
\hline Cap/GDP & $3 . \overline{-} 27$ & 5.353 & 0.000 & 1 & I (I) & Rejected \\
\hline G.Index & $3 . \overline{4} 27$ & $5 . \overline{6} 62$ & 0.022 & 1 & I (I) & Rejected \\
\hline $\mathrm{M} / \mathrm{BV}$ & $3 . \overline{427}$ & $\underset{6.035}{-}$ & 0.045 & 1 & I (I) & Rejected \\
\hline WATDIR & $\overline{3.427}$ & $3 . \overline{9} 45$ & 0.026 & 1 & I (I) & Rejected \\
\hline EPS & $3 . \overline{427}$ & 6.026 & 0.001 & 1 & $\mathrm{I}(\mathrm{I})$ & Rejected \\
\hline DYR & $3 . \overline{427}$ & $6 . \overline{2} 14$ & 0.000 & 1 & $\mathrm{I}(\mathrm{I})$ & Rejected \\
\hline No. of Transactions & $3 . \overline{427}$ & $4 . \overline{4} 49$ & 0.000 & 1 & $\mathrm{I}(\mathrm{I})$ & Rejected \\
\hline WASDIR & $\overline{3.427}$ & $4 . \overline{-}$ & 0.006 & 1 & I (I) & Rejected \\
\hline $\mathrm{P} / \mathrm{E}$ & 3.427 & 5.098 & 0.000 & 1 & $\mathrm{I}(\mathrm{I})$ & Rejected \\
\hline RFC_2008/11 & $3 . \overline{4} 27$ & $5 . \overline{9} 28$ & 0.000 & 1 & I (I) & Rejected \\
\hline
\end{tabular}

Note: ${ }^{* * *}$ indicates that the time series variables are significant at 5 per cent level of significance.

term's coefficient equals zero. Thus, this null hypothesis is tested against the alternative one, which assumes that the error term $\neq 0$.

\section{Results and discussion}

The current research analyzed a monthly data set to determine the influential variables of investors' perceptions as captured by the performance of ASE. Thus, after checking for data stationarity, results from ADF test indicated that variables including Cap/GDP, G.Index, M/BV, WATDIR, EPS, DYR, No. of Transactions, WASDIR, P/E and RFC_2008/11 are found to be non-stationary when they are tested at their levels 5\%. However, after converting them into the first difference, findings from the following table (Table 1) confirmed that the null hypothesis was rejected, which in other words the variables became stationary. Thereafter, the study moved on to run the Johansen co-integration test.

After employing the Johansen Co-integration test, the results as shown in Table 2 indicated that the Trace statistics are higher than their critical values at the level $99 \%$. Therefore, the null hypothesis was rejected, which in other words means that IP as captured by the general stock index are statistically integrated with the monthly change in market fundamentals, dividends policies and the 2008/11 crisis. Thus, since the results confirmed at least a one cointegration, the study ran the ECM to check the nature of this long-run association.

In an attempt to check whether this long-run integration is an illusion or not, results from the ECM indicated that since the error term is positive as well as the $\mathrm{P}$-value is higher than the level of significance $1 \%$, statistics from the following Table 3 affirmed that the perceptions of ASE's investors are not being granger caused by the monthly change in dividends policies, market fundamentals or the recent financial crisis, over the long-run. By contrast, results from Waldtest proved that there are statistical causalities running from the monthly movements in interest rates, P/E ratio, No. of transactions and the 2008/11 financial crisis towards the general stock index during the short-run. Additionally, the results showed that the

Table 2. Johansen co-integration results

\begin{tabular}{|c|c|c|c|c|}
\hline \multicolumn{5}{|c|}{$\begin{array}{l}\text { VEC-rank G.Index, DYR, M/BV ratio, EPS, WATDIR. } \\
\text { WASDIR. Cap/GDP, No. Transactions, } \\
\text { P/E, RFC_2008/11, trend(Constant) Lags (3) max } \\
\text { Johansen Co-integration Test }\end{array}$} \\
\hline & & \multicolumn{2}{|c|}{ Trend: Constant } & $\begin{array}{c}\text { No. of } \\
\text { Obs. }=333\end{array}$ \\
\hline & & \multicolumn{2}{|c|}{$\begin{array}{c}\text { Sample: } \\
\text { April 1990-Dec/2017 }\end{array}$} & Lags $=3$ \\
\hline & & \multicolumn{3}{|c|}{ Maximum } \\
\hline Rank & $\begin{array}{l}\text { Eigen } \\
\text { Value }\end{array}$ & $\mathrm{H}_{0}$ & $\begin{array}{c}\text { Trace } \\
\text { Statistics }\end{array}$ & $\begin{array}{l}\text { 1\% Critical } \\
\text { Value }\end{array}$ \\
\hline 0 & . & $\mathrm{R}=0$ & 378.9 & 247.1 \\
\hline 1 & 0.3094 & $\mathrm{R} \leq 1$ & 255.6 & 204.9 \\
\hline 2 & 0.2177 & $\mathrm{R} \leq 2$ & 173.8 & 168.3 \\
\hline 3 & 0.1331 & $\mathrm{R} \leq 3$ & 126.3 & 133.5 \\
\hline 4 & 0.0995 & $\mathrm{R} \leq 4$ & 91.37 & 103.1 \\
\hline 5 & 0.0872 & $\mathrm{R} \leq 5$ & 60.98 & 76.07 \\
\hline 6 & 0.0584 & $\mathrm{R} \leq 6$ & 40.92 & 54.46 \\
\hline 7 & 0.0498 & $\mathrm{R} \leq 7$ & 23.88 & 35.65 \\
\hline 8 & 0.0340 & $\mathrm{R} \leq 8$ & 12.35 & 20.04 \\
\hline 9 & 0.0275 & $\mathrm{R} \leq 9$ & 3.065 & 6.65 \\
\hline 10 & 0.0091 & $\mathrm{R} \leq 10$ & . & . \\
\hline
\end{tabular}


tested variables did not present any autocorrelation at lag one, two or three. For results from Waldand LM tests; see Tables $1-2$ in the appendix.

In addition, although results from Johansen test as demonstrated in Table 4 showed that the Trace Statistics > Critical Values, however, results from the error correction model revealed that investors' perceptions as gauged by the buffet indicator are not being granger caused by the change in market fundamentals, dividends policies or the 2008/11 financial crisis. However, results from the Wald test showed that variables including interest rates, $\mathrm{P} / \mathrm{E}$ ratio, No. of transactions and financial crisis are significantly impacting the Buffet indicator during the short-term. Additionally, results from LM test indicated that there is no

Table 3. Error correction model's results

\begin{tabular}{|c|c|c|c|c|c|c|}
\hline & Coef. & $\begin{array}{l}\text { Std. } \\
\text { Error }\end{array}$ & Z & $\begin{array}{l}\mathrm{P}> \\
\mid \mathrm{Z} /\end{array}$ & $\begin{array}{l}99 \% \\
\text { Conf. }\end{array}$ & $\begin{array}{c}\text { Inter- } \\
\text { val }\end{array}$ \\
\hline \multicolumn{7}{|c|}{ D_G.Index } \\
\hline \multicolumn{7}{|c|}{ _Ce1 } \\
\hline L1. & 0.004 & 0.007 & 0.560 & 0.573 & 0.022 & 0.014 \\
\hline \multicolumn{7}{|c|}{ G. Index } \\
\hline LD. & 0.034 & 0.193 & 0.018 & 0.857 & 0.533 & 0.463 \\
\hline L2D. & 0.052 & 0.198 & 0.260 & 0.793 & 0.460 & 0.564 \\
\hline \multicolumn{7}{|l|}{ EPS } \\
\hline LD. & 0.060 & 0.138 & 0.430 & 0.664 & 0.297 & 0.417 \\
\hline L2D. & 0.026 & 0.092 & 0.290 & 0.771 & 0.210 & 0.264 \\
\hline \multicolumn{7}{|l|}{ DYR } \\
\hline LD. & 12.04 & 145.2 & 0.080 & 0.934 & 362.1 & 386.2 \\
\hline L2D. & 37.62 & 145.8 & 0.260 & 0.796 & 413.2 & 337.9 \\
\hline \multicolumn{7}{|c|}{ WATDIR } \\
\hline LD. & 267.3 & 202.9 & 1.320 & 0.188 & 255.5 & 790.1 \\
\hline L2D. & 340.4 & 181.6 & 1.870 & 0.061 & 127.3 & 808.3 \\
\hline \multicolumn{7}{|c|}{ WASDIR } \\
\hline LD. & 68.9 & 878.7 & 0.080 & 0.973 & 2237 & 2194 \\
\hline L2D. & 563.2 & 854.2 & 0.660 & 0.510 & 2763 & 1637 \\
\hline \multicolumn{7}{|c|}{ MBV Ratio } \\
\hline LD. & 40.17 & 350.5 & 0.110 & 0.909 & 943.0 & 862.6 \\
\hline L2D. & 125.0 & 355.9 & 0.350 & 0.725 & 1041 & 791.8 \\
\hline \multicolumn{7}{|l|}{$\mathrm{PE}$} \\
\hline LD. & 3933 & 2395 & 1.640 & 0.101 & 2237 & 1010 \\
\hline L2D. & 1722 & 2424 & 0.710 & 0.477 & 4522 & 7966 \\
\hline \multicolumn{7}{|c|}{ No. Transactions } \\
\hline LD. & 51.31 & 178.0 & 0.290 & 0.773 & 407.3 & 510.0 \\
\hline L2D. & 448.5 & 174.5 & 2.570 & 0.010 & 898.2 & 1.198 \\
\hline \multicolumn{7}{|c|}{$\mathrm{CAP} / \mathrm{GDP}$} \\
\hline LD. & 23.19 & 819.2 & 0.030 & 0.977 & 2133 & 2087 \\
\hline L2D. & 200.5 & 829.4 & 0.240 & 0.809 & 2337 & 1935 \\
\hline \multicolumn{7}{|c|}{ RFC_2008/11 } \\
\hline LD. & 15.02 & 82.46 & 0.180 & 0.855 & 197.3 & 227.4 \\
\hline L2D. & 12.95 & 79.51 & 0.160 & 0.871 & 191.8 & 217.7 \\
\hline Cons_ & 2.889 & 19.13 & 0.150 & 0.880 & 46.40 & 52.18 \\
\hline
\end{tabular}

autocorrelation in the residual at lag one, two or three. For results from the ECM, Waldand LM tests; see Tables 3-5 in the appendix.

As shown in the following Table (Table 5), results from Johansen test confirmed that there is at least a long-run integration between investors' perceptions as gauged by

Table 4. Johansen co-integration results

VEC-rank CAP/GDP, DYR, M/BV ratio, EPS, WATDIR. WASDIR. G.Index, No. Transactions,

P/E, EPS, RFC_2008/11, trend(Constant) Lags (3) max Johansen Co-integration Test

\begin{tabular}{|c|c|c|c|c|}
\hline & & \multicolumn{2}{|c|}{ Trend: Constant } & $\begin{array}{c}\text { No. of } \\
\text { Obs. }=333\end{array}$ \\
\hline & & \multicolumn{2}{|c|}{$\begin{array}{c}\text { Sample: April 1990- } \\
\text { Dec/2017 }\end{array}$} & Lags $=3$ \\
\hline & & \multicolumn{3}{|c|}{ Maximum } \\
\hline Rank & $\begin{array}{l}\text { Eigen } \\
\text { Value }\end{array}$ & $\mathrm{H}_{0}$ & $\begin{array}{c}\text { Trace } \\
\text { Statistics }\end{array}$ & $\begin{array}{l}1 \% \text { Critical } \\
\text { Value }\end{array}$ \\
\hline 0 & . & $\mathrm{R}=0$ & 378.9 & 247.1 \\
\hline 1 & 0.3094 & $\mathrm{R} \leq 1$ & 255.6 & 204.9 \\
\hline 2 & 0.2177 & $\mathrm{R} \leq 2$ & 173.8 & 168.3 \\
\hline 3 & 0.1331 & $\mathrm{R} \leq 3$ & $126.3^{*}$ & 133.5 \\
\hline 4 & 0.0995 & $\mathrm{R} \leq 4$ & 91.37 & 103.1 \\
\hline 5 & 0.0872 & $\mathrm{R} \leq 5$ & 60.98 & 76.07 \\
\hline 6 & 0.0584 & $\mathrm{R} \leq 6$ & 40.92 & 54.46 \\
\hline 7 & 0.0498 & $\mathrm{R} \leq 7$ & 23.88 & 35.65 \\
\hline 8 & 0.0340 & $\mathrm{R} \leq 8$ & 12.35 & 20.04 \\
\hline 9 & 0.0275 & $\mathrm{R} \leq 9$ & 3.065 & 6.65 \\
\hline 10 & 0.0091 & $\mathrm{R} \leq 0$ & . & . \\
\hline
\end{tabular}

Table 5. Johansen co-integration results

VEC-rank No. Transactions, G.Index, DYR, M/BV ratio, EPS, WATDIR. WASDIR. Cap/GDP, P/E, EPS, RFC_2008/11, trend(Constant) Lags (3) max Johansen Co-integration Test

\begin{tabular}{|c|c|c|c|c|}
\hline \multicolumn{2}{|c|}{} & \multicolumn{2}{c|}{ Trend: Constant } & $\begin{array}{c}\text { No. of } \\
\text { Obs. }=333\end{array}$ \\
\hline \multicolumn{2}{|c|}{} & $\begin{array}{r}\text { Sample: April 1990- } \\
\text { Dec/2017 }\end{array}$ & Lags $=3$ \\
\hline \multicolumn{2}{|c|}{} & \multicolumn{3}{|c|}{ Maximum } \\
\hline \multirow{2}{*}{ Rank } & $\begin{array}{c}\text { Eigen } \\
\text { Value }\end{array}$ & $\mathrm{H}_{0}$ & $\begin{array}{c}\text { Trace } \\
\text { Statistics }\end{array}$ & $\begin{array}{c}1 \% \text { Critical } \\
\text { Value }\end{array}$ \\
\hline 0 &. & $\mathrm{R}=0$ & 378.9 & 247.1 \\
\hline 1 & 0.3094 & $\mathrm{R} \leq 1$ & 255.6 & 204.9 \\
\hline 2 & 0.2177 & $\mathrm{R} \leq 2$ & 173.8 & 168.3 \\
\hline 3 & 0.1331 & $\mathrm{R} \leq 3$ & $126.3 *$ & 133.5 \\
\hline 4 & 0.0995 & $\mathrm{R} \leq 4$ & 91.37 & 103.1 \\
\hline 5 & 0.0872 & $\mathrm{R} \leq 5$ & 60.98 & 76.07 \\
\hline 6 & 0.0584 & $\mathrm{R} \leq 6$ & 40.92 & 54.46 \\
\hline 7 & 0.0498 & $\mathrm{R} \leq 7$ & 23.88 & 35.65 \\
\hline 8 & 0.0340 & $\mathrm{R} \leq 8$ & 12.35 & 20.04 \\
\hline 9 & 0.0275 & $\mathrm{R} \leq 9$ & 3.065 & 6.65 \\
\hline 10 & 0.0091 & $\mathrm{R} \leq 10$ &. &. \\
\hline
\end{tabular}


the number of transactions along with the monthly change in market fundamentals, dividends' policies as well as the 2008/11 financial crisis. Nevertheless, findings from ECM confirmed that investors' perceptions are not being granger caused by market fundamentals, dividends policies or the 2008/11 financial crisis at the level 99\%. Paradoxically, results from Waldtest revealed short-run causalities; those are running from the monthly change in interest rates, $\mathrm{P} / \mathrm{E}$ ratio, and the recent financial crisis towards investors' perceptions. Therefore, it can be induced that investors of Jordan can rely on the movements of dividends policies, and interest rates to anticipate the number of transactions at ASE. Furthermore, results from the LM test confirmed that there is no autocorrelation in the residual at lag one, two or three. For results from the ECM, Waldand LM tests; see Tables 6-8 in the appendix.

\section{Conclusions and recommendations}

Through assessing the impact of dividends policies, market fundamentals as well as the recent financial crisis in investors' perceptions, results from ADF approved that the examined variables are found to be stationary of the same order I (I). However, although results from Johansen showed that the used variables are significantly integrated over the long-run; results from the ECM approved there are no long-run causalities running from dividends policies and market fundamentals towards investors' perceptions as captured by the general stock index, Buffet indicator or the number of transaction, over the long-run.

Similarly, investors' perceptions are found to be unrelated with the market performance, and that agrees with (Ali, 2018b) as he confirmed that investors' behaviour is not associated with interest rates, over the long-run. By contrast, Thang (2009) revealed that stock market's indices are negatively relating to the rates of interest during both the short and long-terms. Additionally, the study revealed that investors' perceptions are not affected by the recent financial crisis during the long-run. However, this result contradicts with Ali (2018a) as he found an adverse correlation of financial crisis along with investors' behaviour.

Furthermore, findings from Wald test confirmed that investors' perceptions are significantly related to market fundamental variables and P/E ratio during the shortrun. Therefore, it is concluded that investors of ASE are including the view of Gordon (1962), in the process of decision making. In this regard, Lintner (1962) affirmed that a firm's value is significantly related to a firm's dividends policies, since the decision of distributing dividends convinces investors to acquire the stock. The results also discovered short-run correlations between No. of transactions and financial crisis along with investors' perceptions as measured by the stock index. By contrast, Al-Majali and Al-Assaf (2014), Mashal (2012) argued that the performance of Amman stock exchange was not impacted by the recent financial crisis due to the low integration of Jordanian economy along with the world economy. Therefore, the current research can induce that investors' perceptions were not impacted by this crisis during the long-run, due to the limited openness of Jordanian economy to the global economy. To some extent that agrees with (Ali, 2016b) as he found that the global crisis was not impacted the Jordanian financial system due to the limited openness to the world economy.

Moreover, due to the vital role of dividends policies and market fundamentals in the process of decision making, the current study recommends investors to rely on the study's results to anticipate the market performance during the short-run. Additionally, the study recommends further researchers to intensify the focus on evaluating the role of dividends policies in the performance of developing stock markets, as well as comparing the impact of these policies in the behaviour of small as well as large investors.

\section{Disclosure statement}

I would like to declare that there is no conflict of interest.

\section{References}

Aharony, J., \& Swary, I. (1980). Quarterly dividend and earnings announcements and stockholders' returns: an empirical analysis. Journal of Finance, 35(1), 1-12.

https://doi.org/10.1111/j.1540-6261.1980.tb03466.x

Ali, M. S. (2018a). In a search for the influential factors of investors' behaviour. In the Proceedings of the ICBEMM 2018 Conference (pp. 26-37). Oxford University, Oxford, UK.

Ali, M. S. (2018b). Interest rates and investors behaviour: cointegration and Granger causality. ACRN Oxford Journal of Finance and Risk Perspectives, 7(1), 1-15.

Ali, M., S. (2016a). M/BV ratio and the liquidity of stock markets: co-integration and Granger causality. In the Proceedings of the 2016 BAFA Annual Conference. University of Bath, Bath, UK.

Ali, M. S. (2016b). The impact of market fundamentals and financial crisis on the liquidity of banks and stock markets: evidence from Jordanian investors (PhD Thesis). Anglia Ruskin University, Cambridge, UK.

AL-Majali, A., \& Al-Assaf, G. (2014). Long-run and short-run relationship between stock market index and main macroeconomic variables performance in Jordan. European Scientific Journal, 10(10), 156-171.

Al-Mukit, D. M. (2012). Effect of interest rate and exchange rate on volatility of market Index at Dhaka stock exchange. Journal of Business and Technology (Dhaka), 7(2), 1-18. https://doi.org/10.3329/jbt.v7i2.16451

Al-Najjar, F., Noor, M., Al-Ahmed, N., \& Issa, S. (2010). The global financial crisis and its impact on the financial sector in Jordan: applied study on financial companies listed in Amman stock exchange. The Journal of International Finance and Economics, 10(1), 01-13.

Al-Zyadat, A., \& Al-Kharabsheh, F. (2013). Financial crisis impact on world financial markets: an applied case on Jordan stock market. The Journal of Islamic University for Economic and Managerial Studies, 21, 399-426.

Amman Stock Exchange. (2018). Disclosures. https://www.ase.com.jo/en/disclosures

Aurangzeb. (2012). Factors affecting performance of stock market: evidence from South Asian countries. International Journal of Academic Research in Business and Social Sciences, 2(9), 01-15. 
Azam, M., \& Kumar, D. (2011). Factors influencing the individual investor and stock price variation: evidence from Karachi stock exchange. Australian Journal of Basic and Applied Sciences, 5(12), 3040-3043.

Balakrishnan, K. P. (2016). A study on impact of earnings per share, dividend per share and price earnings ratio on behaviour of share market price movement (Pharma Sector) with special reference to NSE. IJARIIE, 2(1), 2395-4396.

Balaputhiran, S. (2014). Firm performance and earnings per share: A study of listed banks in Sri Lanka. Merit Research Journal of Accounting, Auditing, Economics and Finance, 2(1), 008-011.

Black, F., \& Scholes, M. (1974). The effects of dividend yield and dividend policy on common stock prices and returns. Journal of Financial Economics, 1(1), 1-22.

https://doi.org/10.1016/0304-405X(74)90006-3

Central Bank of Jordan. (2018). Statistical database. http://www.cbj.gov.jo/Pages/viewpage.aspx?pageID=210

El-Seoud, M. (2014). Private saving determinants in Bahrain. International Journal of Economics, Commerce and Management, 2(4), 1-21.

Global Economy. (2018). International data only a mouse click. http://www.theglobaleconomy.com/?3

Gordon, M. J. (1962). The savings investment and valuation of a corporation. The Review of Economics and Statistics, 44, 37-51. https://doi.org/10.2307/1926621

Gordon, M., J. (1959). Dividends, earnings, and stock prices. The Review of Economics and Statistics, 41(2), 99-105. https://doi.org/10.2307/1927792

Harsha, J., \& Kerav, P. (2012). Investors' behaviour of equity investment: an empirical study of individual investors. GFJMR, 5, 01-33.

Khan, M. K., Tend, J.-Z., \& Khan, M. I. (2019). Asymmetric impact of oil prices on stock returns in Shanghai stock exchange: Evidence from asymmetric ARDL model. Plos One, 14(6), 1-14. https://doi.org/10.1371/journal.pone.0218289

Khrawish, H., Siam, W., \& Jaradat, M. (2010). The relationships between stock market capitalization rate and interest rate: evidence from Jordan. Central and Eastern European Online Library, 2(2), 60-66. https://doi.org/10.15208/beh.2010.17

Lintner, J. (1962). Dividends, earnings, leverage, stock prices and supply of capital to corporations. The Review of Economics and Statistics, 64, 243-269. https://doi.org/10.2307/1926397

Mashal, A. (2012). The financial crisis of 2008-2009 and the Arab States' economies. International Journal for Business and Management, 7(4), 96-111.

https://doi.org/10.5539/ijbm.v7n4p96
Miller, M., \& Modigliani, F. (1961). Dividend policy, growth, and the valuation of shares. The Journal of Business, 34(4), 411-433. https://doi.org/10.1086/294442

Mojgan, S., \& Ali, M. (2011). Examining the effect of earnings per share and cash dividends per share on investor decision making in Tehran stock exchange from the capital market participants' view. American Journal of Scientific Research, 36, 99-106.

Neaime, S. (2012). The global financial crisis, financial linkages and correlations in returns and volatilities in emerging MENA stock markets. Elsevier, 13, 268-282. https://doi.org/10.1016/j.ememar.2012.01.006

Ologunde, A., Elumilade, O., \& Saolu, T. (2006). Stock market capitalization and interest rate in Nigeria: a times series analysis. International Research Journal of Finance and Economics, $4,154-167$.

Richard, A., Adekunie, O., \& Ojodu, H. (2012). Impact of interest rate on capital market growth: a case of Nigeria. Universal Journal of Management and Social Sciences, 2(11), 12-1213.

Saunders, M., Lewis, P., \& Thornhill, A. (2012). Research methods for business students ( $6^{\text {th }}$ ed.). Harlow: Pearson Education Limited.

Seetharaman, A., \& Raj, J. (2011). An empirical study on the impact of earnings per share on stock prices on a listed bank in Malaysia. The International Journal of Applied Economics and Finance, 5(2), 114-126.

https://doi.org/10.3923/ijaef.2011.114.126

Shaban, O. S., \& Zubi, Z. (2014). The role of financial indicators in rationalizing of investors' decisions in the Jordanian stock exchange market. In the Proceedings of 2014 ATINER'S Conference. Athens, Greece.

Thang, F. (2009). The impact of interest rate and exchange rate on the stock market index in Malaysia: a cointegration analysis (MS Thesis). University of Sains Malaysia, Penang, Malaysia.

The World Bank. (2018). IBRD.IDA. http://www.worldbank.org/

Yamin, I., \& Ali, M. S. (2014). The impact of the volatility in banks performance indicators on stock prices: an empirical study on Jordanian listed banks. Zarqa Journal for Research and Studies in Humanities, 14(1), 291-302. https://doi.org/10.12816/0020148

Zafar, M. (2013). Determinants of stock market performance in Pakistan. Interdisciplinary Journal of Contemporary Research in Business, 4(9), 1017-1026. 


\section{APPENDIX}

Table 1. Wald test's results

\begin{tabular}{|c|c|c|}
\hline \multicolumn{3}{|c|}{$\begin{array}{c}\text { This table indicates that there are short-run causalities } \\
\text { running from interest rates, P/E ratio, No. of transactions } \\
\text { and RFC_2008/11 towards investors' perceptions. }\end{array}$} \\
\hline Variable & Chi2 & Prob>chi2 \\
\hline EPS & 4.73 & 0.99 \\
\hline DYR & 10.4 & 0.96 \\
\hline WASDIR & 370 & 0.00 \\
\hline WATDIR & 85.8 & 0.00 \\
\hline M/BV & 16.3 & 0.69 \\
\hline P/E & 811 & 0.00 \\
\hline No. Transactions & 64.6 & 0.00 \\
\hline CAP/GDP & 15.4 & 0.75 \\
\hline RFC_2008/11 & 65.7 & 0.00 \\
\hline
\end{tabular}

Table 2. LM test

This table confirmed that the tested variables did not present any autocorrelation at lag one, two or three.

\begin{tabular}{|c|c|c|c|}
\hline Lag & Chi2 & Df & Prob>chi2 \\
\hline 1 & 90.6 & 100 & 0.73 \\
\hline 2 & 106 & 100 & 0.31 \\
\hline 3 & 80.9 & 100 & 0.91 \\
\hline
\end{tabular}

Table 3. Error correction model

\begin{tabular}{|c|c|c|c|c|c|c|}
\hline \multicolumn{7}{|c|}{$\begin{array}{l}\text { Since the error term is positive as well as the P-value is not significant, investors' perceptions is found not to be correlated with } \\
\text { dividends policies, market fundamentals or the financial crisis, over the long-run }\end{array}$} \\
\hline & Coef. & Std. Error & $\mathrm{Z}$ & $\mathrm{P}>/ \mathrm{Z} \mid$ & 99\% Conf. & Interval \\
\hline \multicolumn{7}{|c|}{ DCAP/GDP } \\
\hline \multicolumn{7}{|l|}{ Ce1 } \\
\hline L1. & 0.001 & 0.002 & 0.540 & 0.588 & 0.005 & 0.008 \\
\hline \multicolumn{7}{|c|}{ CAP/GDP } \\
\hline LD. & 0.007 & 0.215 & 0.030 & 0.974 & 0.562 & 0.548 \\
\hline L2D. & 0.177 & 0.218 & 0.810 & 0.417 & 0.740 & 0.385 \\
\hline \multicolumn{7}{|l|}{ EPS } \\
\hline LD. & 0.000 & 0.000 & 0.440 & 0.659 & 0.000 & 0.000 \\
\hline L2D. & 7.600 & 0.000 & 0.310 & 0.754 & 0.000 & 0.000 \\
\hline \multicolumn{7}{|l|}{ DYR } \\
\hline LD. & 0.007 & 0.038 & 0.180 & 0.855 & 0.091 & 0.105 \\
\hline L2D. & 0.010 & 0.038 & 0.280 & 0.777 & 0.109 & 0.088 \\
\hline \multicolumn{7}{|c|}{ WATDIR } \\
\hline LD. & 0.081 & 0.053 & 1.520 & 0.128 & 0.056 & 0.219 \\
\hline L2D. & 0.035 & 0.047 & 0.750 & 0.456 & 0.087 & 0.158 \\
\hline \multicolumn{7}{|c|}{ WASDIR } \\
\hline LD. & 0.043 & 0.231 & 0.190 & 0.851 & 0.639 & 0.552 \\
\hline L2D. & 0.090 & 0.225 & 0.400 & 0.687 & 0.670 & 0.489 \\
\hline \multicolumn{7}{|c|}{ MBV Ratio } \\
\hline LD. & 0.005 & 0.092 & 0.060 & 0.956 & 0.242 & 0.232 \\
\hline L2D. & 0.011 & 0.039 & 0.120 & 0.904 & 0.252 & 0.230 \\
\hline \multicolumn{7}{|l|}{$\mathrm{PE}$} \\
\hline LD. & 0.991 & 0.631 & 1.570 & 0.116 & 0.634 & 2.617 \\
\hline L2D. & 0.420 & 0.638 & 0.660 & 0.510 & 1.224 & 2.065 \\
\hline \multicolumn{7}{|c|}{ No. Transactions } \\
\hline LD. & 0.011 & 0.046 & 0.240 & 0.814 & 0.109 & 0.000 \\
\hline L2D. & 0.090 & 0.045 & 1.970 & 0.049 & 0.208 & 0.028 \\
\hline \multicolumn{7}{|c|}{ G.Stock Index } \\
\hline LD. & 7.840 & 0.021 & 0.150 & 0.878 & 0.001 & 0.000 \\
\hline L2D. & 0.000 & 0.000 & 0.780 & 0.434 & 0.009 & 0.000 \\
\hline \multicolumn{7}{|c|}{ RFC2008/11 } \\
\hline LD. & 0004 & 0.021 & 0.22 & 0.830 & 0.051 & 0.060 \\
\hline L2D. & 0.001 & 0.020 & 0.090 & 0.926 & 0.052 & 0.055 \\
\hline Cons & 0.001 & 0.005 & 0.250 & 0.804 & 0.014 & 0.011 \\
\hline
\end{tabular}


Table 4. Wald test's results

\begin{tabular}{|c|c|c|}
\hline \multicolumn{3}{|c|}{$\begin{array}{c}\text { This table indicates that there are short-run causalities } \\
\text { running from interest rates, P/E ratio, No. of transactions and } \\
\text { RFC_2008/11 towards investors' perceptions. }\end{array}$} \\
\hline $\begin{array}{c}\text { Variable } \\
\text { EPS }\end{array}$ & Chi2 & Prob.>chi2 \\
\hline DYR & 4.73 & 0.99 \\
\hline WASDIR & 10.41 & 0.96 \\
\hline WATDIR & 870 & 0.00 \\
\hline M/BV & 16.3 & 0.00 \\
\hline P/E & 811 & 0.69 \\
\hline No. Transactions & 64.6 & 0.00 \\
\hline G.Stock Index & 27.7 & 0.00 \\
\hline RFC_2008/11 & 65.7 & 0.11 \\
\hline
\end{tabular}

Table 5. LM results

\begin{tabular}{|c|c|c|c|}
\hline \multicolumn{4}{|c|}{$\begin{array}{l}\text { This table revealed that there is no autocorrelation in the } \\
\text { residual at lag one, two or three. }\end{array}$} \\
\hline Lag & Chi2 & Df & Prob.> chi2 \\
\hline 1 & 90.62 & 100 & 0.738 \\
\hline 2 & 106.3 & 100 & 0.313 \\
\hline 3 & 80.97 & 100 & 0.918 \\
\hline
\end{tabular}

Table 6. Error correction model

\begin{tabular}{|c|c|c|c|c|c|c|}
\hline & Coef. & Std. Error & $\mathrm{Z}$ & $\mathrm{P}>\mid \mathrm{Z} /$ & 99\% Conf. & Interval \\
\hline \multicolumn{7}{|c|}{ DNo. of Transactions } \\
\hline \multicolumn{7}{|c|}{ Ce1 } \\
\hline L1. & 0.000 & 0.000 & 0.360 & 0.721 & 0.001 & 0.001 \\
\hline \multicolumn{7}{|c|}{ No. Of Transactions } \\
\hline LD. & 0.147 & 0.060 & 2.430 & 0.015 & 0.008 & 0.302 \\
\hline L2D. & 0.045 & 0.059 & 0.770 & 0.444 & 0.107 & 0.198 \\
\hline \multicolumn{7}{|c|}{ CAP/GDP } \\
\hline LD. & 0.042 & 0.278 & 0.150 & 0.879 & 0.674 & 0.758 \\
\hline L2D. & 0.025 & 0.281 & 0.090 & 0.927 & 0.751 & 0.699 \\
\hline \multicolumn{7}{|l|}{ EPS } \\
\hline LD. & 6.270 & 0.000 & 0.130 & 0.894 & 0.001 & 0.000 \\
\hline L2D. & 6.150 & 0.000 & 0.200 & 0.844 & 0.008 & 0.000 \\
\hline \multicolumn{7}{|l|}{ DYR } \\
\hline LD. & 0.012 & 0.049 & 0.250 & 0.802 & 0.114 & 0.139 \\
\hline L2D. & 0.012 & 0.049 & 0.260 & 0.795 & 0.140 & 0.114 \\
\hline \multicolumn{7}{|c|}{ WATDIR } \\
\hline LD. & 0.031 & 0.068 & 0.460 & 0.647 & 0.145 & 0.209 \\
\hline L2D. & 0.031 & 0.061 & 0.510 & 0.610 & 0.127 & 0.190 \\
\hline \multicolumn{7}{|c|}{ WASDIR } \\
\hline LD. & 0.079 & 0.298 & 0.270 & 0.791 & 0.847 & 0.689 \\
\hline L2D. & 0.116 & 0.289 & 0.400 & 0.689 & 0.863 & 0.630 \\
\hline \multicolumn{7}{|c|}{ MBV Ratio } \\
\hline LD. & 0.022 & 0.118 & 0.190 & 0.852 & 0.328 & 0.284 \\
\hline L2D. & 0.025 & 0.120 & 0.210 & 0.832 & 0.336 & 0.285 \\
\hline \multicolumn{7}{|l|}{$\mathrm{PE}$} \\
\hline LD. & 0.840 & 0.813 & 1.030 & 0.302 & 1.254 & 2.934 \\
\hline L2D. & 0.154 & 0.822 & 0.190 & 0.851 & 1.964 & 2.274 \\
\hline \multicolumn{7}{|c|}{ G.Stock Index } \\
\hline LD. & 7.340 & 0.000 & 0.110 & 0.911 & 0.001 & 0.000 \\
\hline L2D. & 7.050 & 0.000 & 0.100 & 0.917 & 0.001 & 0.000 \\
\hline \multicolumn{7}{|c|}{ RFC2008/11 } \\
\hline LD. & 0.049 & 0.027 & 1.770 & 0.077 & 0.121 & 0.022 \\
\hline L2D. & 0.003 & 0.026 & 0.140 & 0.889 & 0.073 & 0.065 \\
\hline Cons & 0.007 & 0.006 & 0.120 & 0.905 & 0.017 & 0.015 \\
\hline
\end{tabular}


Table 7. Wald test's results

\begin{tabular}{|c|c|c|}
\hline \multicolumn{3}{|c|}{$\begin{array}{c}\text { This table confirmed that there are short-run } \\
\text { causalities running from interest rates, P/E ratio, and } \\
\text { RFC_2008/11 towards investors' perceptions. }\end{array}$} \\
\hline Variable & Chi2 & Prob.> chi2 \\
\hline CAP/GDP & 15.40 & 0.752 \\
\hline EPS & 4.73 & 0.99 \\
\hline DYR & 10.41 & 0.96 \\
\hline WASDIR & 370 & 0.00 \\
\hline WATDIR & 85.8 & 0.00 \\
\hline M/BV & 16.3 & 0.69 \\
\hline P/E & 811 & 0.00 \\
\hline G.Stock Index & 27.7 & 0.11 \\
\hline RFC_2008/11 & 65.7 & 0.00 \\
\hline
\end{tabular}

Table 8. LM results

\begin{tabular}{|c|c|c|c|}
\hline \multicolumn{3}{|c|}{$\begin{array}{c}\text { This table showed that there is no autocorrelation in the } \\
\text { residual at lag one, two or three. }\end{array}$} \\
\hline Lag & Chi2 & Df & Prob >chi2 \\
\hline 1 & 90.62 & 100 & 0.738 \\
\hline 2 & 106.3 & 100 & 0.313 \\
\hline 3 & 80.97 & 100 & 0.918 \\
\hline
\end{tabular}

